\title{
Valorization of Distillery Stillage for Bioenergy Production: A Review
}

\author{
Magdalena Zielińska * (), Katarzyna Bułkowska (1) and Wioleta Mikucka
}

check for updates

Citation: Zielińska, M.; Bułkowska, K.; Mikucka, W. Valorization of Distillery Stillage for Bioenergy Production: A Review. Energies 2021, 14, 7235. https://doi.org/10.3390/ en14217235

Academic Editor: Francesco Frusteri

Received: 30 September 2021

Accepted: 29 October 2021

Published: 2 November 2021

Publisher's Note: MDPI stays neutral with regard to jurisdictional claims in published maps and institutional affiliations.

Copyright: (c) 2021 by the authors. Licensee MDPI, Basel, Switzerland. This article is an open access article distributed under the terms and conditions of the Creative Commons Attribution (CC BY) license (https:/ / creativecommons.org/licenses/by/ $4.0 /)$.
Department of Environmental Biotechnology, University of Warmia and Mazury in Olsztyn, Słoneczna St. 45G, 10-709 Olsztyn, Poland; katarzyna.bulkowska@uwm.edu.pl (K.B.); wioleta.mikucka@uwm.edu.pl (W.M.)

* Correspondence: magdalena.zielinska@uwm.edu.pl; Tel.: +48-89-523-41-85

\begin{abstract}
In alcohol distilleries, the amount of distillery stillage generated can be up to 15 times larger than the amount of alcohol produced. The stillage has high concentrations of organics and nitrogen, a low $\mathrm{pH}$, and a dark brown color. Currently, stillage is mainly used for soil fertilization. For this purpose, it requires thickening and is used seasonally, which creates storage problems and transport costs. To reduce environmental pollution, physicochemical and biological processes have been employed for the treatment of distillery stillage. However, according to bioeconomy principles, the stillage should be transformed into value-added products. Therefore, this review paper focuses on methods of stillage processing that enable energy recovery. Due to its high content of organic compounds, stillage is often used as a raw material for biogas production. Accordingly, anaerobic digestion of stillage is discussed, including an overview of the bioreactors used and the effects of operational parameters on organics removal and biogas production. The necessity of integrating anaerobic stillage treatment with other treatment processes is presented. As complex compounds that are present in the stillage (mainly polyphenols and melanoidin) are difficult to biodegrade and have antibacterial activities, the effect of their recovery on biogas production is described. Next, the possibility of converting distillery stillage to bioethanol and biohydrogen is presented. In addition, bioelectrochemical treatment of distillery stillage using microbial fuel cells is discussed. For all these treatment methods, current challenges and opportunities are given.
\end{abstract}

Keywords: biomethane; bioethanol; biohydrogen; bioelectrochemical treatment; polyphenols; melanoidin

\section{Introduction}

The management of industrial waste is a principal area of development in the world, as industrial waste contains a wide variety of organic and inorganic pollutants that have a negative impact on the environment. The distillery industry is one of the main sources of environmental pollution, but also one of the key factors contributing to the development of the global economy. Only 5\% of the world's ethanol production comes from chemical synthesis. More than $95 \%$ of ethanol is produced from agricultural raw materials. Of these, sugar-based raw materials account for approximately $42 \%$ of the ethanol produced, and non-sugar raw materials (mainly starch-based) account for approximately 58\% [1]. Ethanol is produced from cereals (mainly rye, corn, triticale, and wheat), root crops (mainly potatoes), molasses, and other agricultural raw materials [2]. The production of alcohol is constantly growing because it is used in many industries, including the chemical, pharmaceutical, cosmetic, beverage, food, and perfume industries. In addition, the European Union program obliges Member States to use biofuels as transport fuels (their share should amount to $14 \%$ in 2025 and $19.7 \%$ in 2030) [3]. Along with the increase in the demand for alcohol, the amount of byproducts (termed distillery stillage), which may be up to 15 times greater than the amount of alcohol produced, is also increasing [4]. Treatment of distillery byproducts is a priority area for environmental protection because untreated byproducts that are released into the environment increase water pollution, adversely affect aquatic life, and reduce soil alkalinity. The literature indicates that the most promising 
option for utilization of distillery byproducts is to valorize them as a renewable feedstock for recovery of energy and biobased materials, thus enabling integration of remediation and recovery of resources. In this biorefinery approach, appropriate technologies are required, including methanogenesis, photosynthesis, photofermentation, dark fermentation, and bioelectrogenesis, which are made possible by the versatile metabolisms of biocatalytic micro-organisms.

\section{Generation of Distillery Stillage}

There are four main stages in the production of alcohol: feed preparation, fermentation, distillation, and packaging. As a result of delignification and hydrolysis, cellulosic materials in grain are converted into simple sugars, and then alcohol and carbon dioxide are produced by the fermentation process. The alcohol is recovered from the fermentation solution under reduced pressure and then distilled [5]. In Figure 1, individual stages of alcohol production are shown, with an indication of the types of wastes generated at each stage. In stage I, feedstock materials are pretreated to convert complex compounds into fermentable sugars and inoculated with yeasts. After fermentation (stage II), the sludge (mainly culture yeasts) is circulated to the fermenter, whereas the fermentation broth is directed to the distillation step (stage III). The bottom discharge of the first stage of distillation is distillery stillage, whereas alcohol is directed into the rectification column.

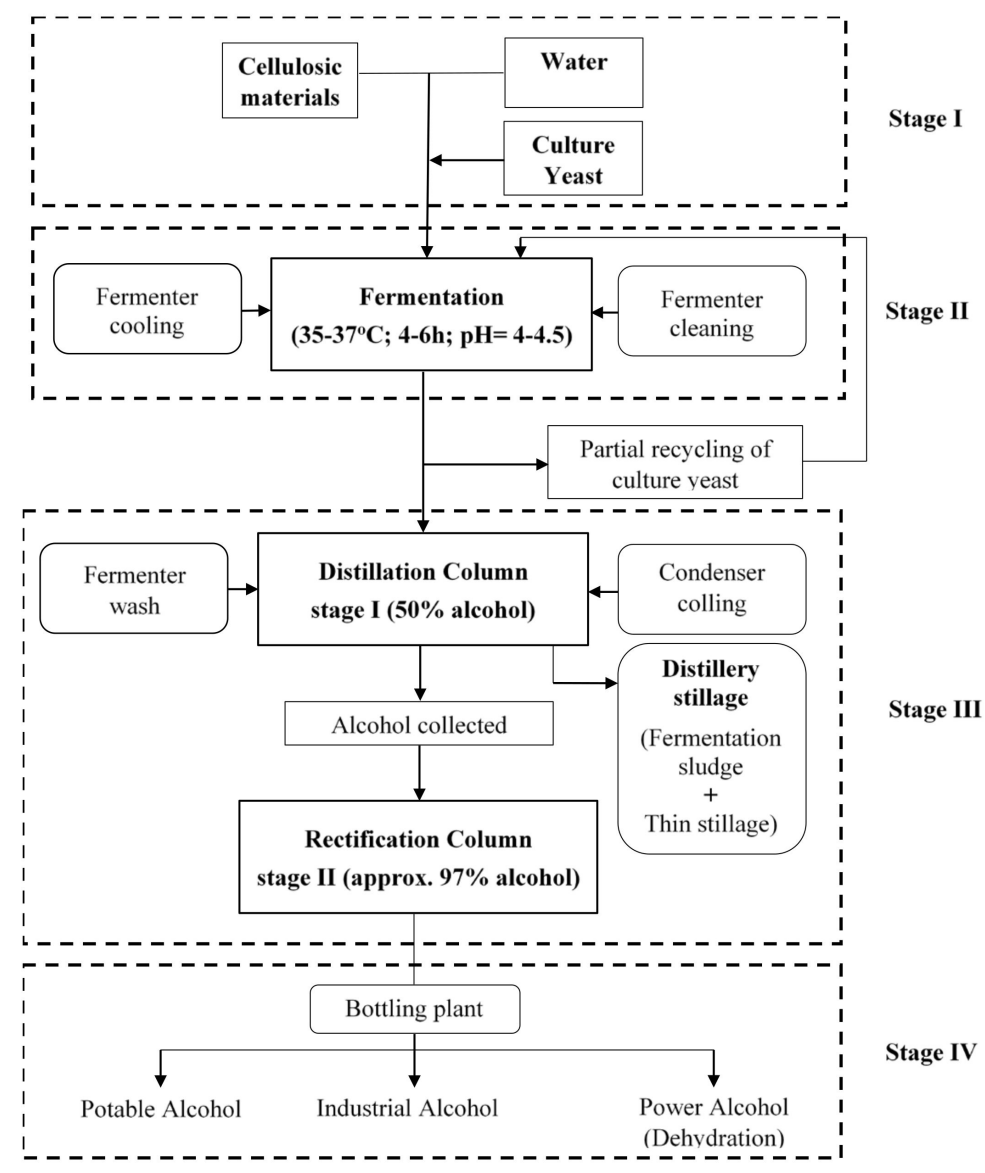

Figure 1. Alcohol production (stage I: feed preparation; stage II: fermentation; stage III: distillation; stage IV: packaging).

As can be seen in Figure 1, there are two types of waste generated in a distillery: process waste and non-process waste. Non-process waste is the wastewater from cleaning, cooling, and rinsing that is generated at different stages of alcohol production; it is relatively clean and can be cooled and recycled without pretreatment [6]. The characteristics of these wastes are presented in Table 1. 
Conventional batch-type distilleries produce $15 \mathrm{~L}$ of process waste per $1 \mathrm{~L}$ of alcohol produced; in modern continuous-type distilleries, this waste amounts to 10-12 L per L of alcohol produced [7]. The process waste from the distillery is called distillery stillage and contains fiber, oil, protein, other unfermented components of the grain, and yeast cells. The stillage is usually centrifuged to produce a liquid fraction (thin stillage) and a solid fraction (fermentation sludge, also called wet distillers' grains) (Table 1). Fermentation sludge is a solid residue from fermentation, ethanol distillation, and centrifugation. Wet distillers' grains alone or in combination with thin stillage (wet distillers' grains with solubles (WDGS)) can be sold as animal feed; a combination of wet distillers' grains and syrup is often dried to greatly lengthen its safe storage, producing dried distillers' grains with solubles (DDGS) [8]. The fermentation sludge contains yeast (Saccharomyces cerevisiae), which can be diluted (if necessary) and recycled back to the fermentation unit to maintain the yeast concentration [7]. Thin stillage is the liquid residue from centrifugation of the whole stillage, which still contains $5-10 \%$ solids [6]. A significant fraction ( $15 \%$ or more) of thin stillage is recycled as a backset to be used as process water at the front end of the process for slurrying the ground grain [9]. The remaining thin stillage is concentrated through multiple-effect evaporators to produce a syrup called condensed distillers' solubles (CDS) [10].

Process waste from the distillery is characterized by a higher concentration of organic compounds and a darker color than non-process waste. Its content of chemical oxygen demand (COD) and biochemical oxygen demand (BOD), and its dark color result from the presence of organic compounds, such as polyphenols, melanoidins, waxes, polysaccharides, reduced sugars, lignin, proteins, carotenoids, chlorophyll, anthocyanins, tannins, etc., which are difficult to biodegrade and inhibit biological activity [11,12]. Melanoidins are formed by the Maillard reaction or nonenzymatic browning reactions that involve amino acids and carbohydrates at temperatures above $50{ }^{\circ} \mathrm{C}$ and $\mathrm{pH}$ values ranging from 4.0 to 7.0 [13]. Melanoidins are difficult to characterize because of their different sizes and the different types of sugars and amino acids involved in their formation. The polyphenols found in distillery stillage fall into three main classes: phenolic acids, flavonoids, and tannins. Polyphenolic compounds and melanoidins in wastewater are the main factors contributing to its antimicrobial activity [14], which limits microbial degradation. Additionally, melanoidin and polyphenols obtained from various sources display antihypertensive, anti-inflammatory, anticancer, and antiglycation effects [15-17].

Due to the soluble organic matter it contains, stillage is considered a troublesome and potentially contaminating waste. The color of distillery waste hinders its oxygenation and self-cleaning [18]. Treatment of this stream is difficult because of the large volumes of wastewater and the presence of certain resistant compounds. Many studies mainly focused on the composition of distillery stillage only and its nutritional value, given its main utilization as animal feed. Another concept of its management is an environmentally friendly method of disposal to reduce a load of pollutants to the level compliant with applicable regulations and standards. Due to the high concentration of organic matter and dissolved organic compounds, stillage treatment mainly involves energy recovery via biomethanation. On average, $38-40 \mathrm{~m}^{3}$ of biogas is produced from $1 \mathrm{~m}^{3}$ of distillery stillage [7].

Table 1. Chemical and physical characteristics of process and non-process waste.

\begin{tabular}{|c|c|c|c|c|c|c|c|c|}
\hline \multirow[b]{2}{*}{ Parameters } & \multicolumn{5}{|c|}{ Non-Process Waste } & \multicolumn{2}{|c|}{ Process Waste } & \multirow[b]{2}{*}{ References } \\
\hline & $\begin{array}{l}\text { Fermenter } \\
\text { Cooling }\end{array}$ & $\begin{array}{l}\text { Fermenter } \\
\text { Cleaning }\end{array}$ & $\begin{array}{l}\text { Condenser } \\
\text { Cooling }\end{array}$ & $\begin{array}{l}\text { Fermenter } \\
\text { Wash }\end{array}$ & BottlingPlant & $\begin{array}{l}\text { Fermentation } \\
\text { Sludge }\end{array}$ & Thin Stillage & \\
\hline Color & Colorless & Colorless & Colorless & Colorless & Colorless & Dark brown & Dark brown & {$[18,19]$} \\
\hline $\mathrm{pH}$ & 6.25 & $5.0-5.5$ & $6.8-7.8$ & 6 & 7.45 & 4.44 & 4.56 & {$[4,19]$} \\
\hline Total solids $(\mathrm{mg} / \mathrm{L})$ & $1000-1300$ & $1000-1500$ & $700-900$ & 550 & 400 & 5500 & 34,000 & {$[4,18]$} \\
\hline $\begin{array}{c}\text { Suspended solids } \\
(\mathrm{mg} / \mathrm{L})\end{array}$ & 220 & $400-600$ & $180-200$ & 300 & 100 & 4300 & 33,100 & {$[5,19]$} \\
\hline $\mathrm{COD}(\mathrm{mg} / \mathrm{L})$ & $500-1000$ & $1200-1600$ & $1200-1600$ & 25 & 15 & $60,000-67,000$ & $80,000-100,000$ & {$[4,18]$} \\
\hline
\end{tabular}


Table 1. Cont

\begin{tabular}{|c|c|c|c|c|c|c|c|c|}
\hline \multirow[b]{2}{*}{ Parameters } & \multicolumn{5}{|c|}{ Non-Process Waste } & \multicolumn{2}{|c|}{ Process Waste } & \multirow[b]{2}{*}{ References } \\
\hline & $\begin{array}{l}\text { Fermenter } \\
\text { Cooling }\end{array}$ & $\begin{array}{l}\text { Fermenter } \\
\text { Cleaning }\end{array}$ & $\begin{array}{l}\text { Condenser } \\
\text { Cooling }\end{array}$ & $\begin{array}{l}\text { Fermenter } \\
\text { Wash }\end{array}$ & BottlingPlant & $\begin{array}{l}\text { Fermentation } \\
\text { Sludge }\end{array}$ & Thin Stillage & \\
\hline $\mathrm{BOD}(\mathrm{mg} / \mathrm{L})$ & $100-110$ & $500-600$ & $70-80$ & 15 & 5 & $35,000-40,000$ & $50,000-600,000$ & {$[4,18]$} \\
\hline VFA (mg/L) & $90-100$ & $250-330$ & $35-50$ & - & - & $500-800$ & $250-280$ & {$[5,19]$} \\
\hline Alkalinity (meq/L) & 300 & - & - & 40 & 80 & 6000 & 9860 & [18] \\
\hline $\mathrm{TP}(\mathrm{mg} / \mathrm{L})$ & $10-15$ & $15-30$ & 20 & - & - & 2500 & 2700 & [4] \\
\hline $\mathrm{PO}_{4}{ }^{3-}(\mathrm{mg} / \mathrm{L})$ & - & - & - & - & - & 1000 & 1000 & {$[5,18]$} \\
\hline $\mathrm{TN}(\mathrm{mg} / \mathrm{L})$ & $20-30$ & $25-40$ & $10-30$ & - & - & 5000 & 7000 & [4] \\
\hline $\mathrm{NH}_{4}{ }^{+}(\mathrm{mg} / \mathrm{L})$ & - & - & - & - & - & 1100 & 2800 & [19] \\
\hline
\end{tabular}

\section{Processing of Distillery Stillage-Biomethane Production}

Distillery stillage has a high energy potential (13.6 MJ/kg TS, 10.4 MJ/kg COD), which indicates that it can be processed via anaerobic digestion and is a suitable substrate for conversion into energy [20]. Distillery stillage consists of compounds that are easily biodegraded during anaerobic digestion, such as proteins, lipids, and carbohydrates. Among the carbohydrates, the concentration of cellulose can be on the level of $32.2 \%$, hemicelluloses-20.9\%, and lignin-3.2\% in the distillery stillage obtained from maize [21]. The higher lignin content is reported in the lignocellulosic biomass, such as sugarcane bagasse-around 20\%, cellulose-23\%, and hemicelluloses-4.30\% [22].

The degradation of substrates with a high protein content results in a high level of ammonium $\left(\mathrm{NH}_{4}{ }^{+}-\mathrm{N}\right)$ in the residue, which causes process instability and reduced biogas / methane production [23]. At a $\mathrm{NH}_{4}{ }^{+}-\mathrm{N}$ concentration above $3 \mathrm{~g} / \mathrm{L}$, acetate degradation changes from acetotrophic methanogenesis to syntrophic acetate oxidation [24,25]. The syntrophic co-operation between syntrophic acetate-oxidizing (SAO) bacteria and hydrotrophic methanogens means that the oxidation of acetate is combined with hydrogen consumption. Cocultures of SAO bacteria and methanogens usually have a lower growth rate than acetic methanogens, which decreases biogas production.

Another ingredient influencing anaerobic digestion is sulfuric acid, which is used to regulate the $\mathrm{pH}$ during alcohol production. This contributes to the high concentration of sulfates in distillery stillage [26]. Sulfate-reducing bacteria convert sulfates into sulfides [27]. Degradation of amino acids releases sulfides from the amino acids, methionine and cysteine, which results in the release of organic sulfur in the form of sulfides. Sulfides cause corrosion, decrease the bioavailability of trace elements essential for microbial activity by forming complexes with metals, and inhibit the growth of micro-organisms and the consumption of organic compounds (mainly alcohols, volatile fatty acids (VFAs)) and hydrogen, which could be used for biogas production [28,29].

Anaerobic digestion of distillery stillage produces digested sludge, which is rich in nutrients [7] and can be used as manure. Before the treated effluent can be released into the environment, it requires further treatment. The major challenges in treating this anaerobically digested effluent are the removal of color and inorganic compounds.

\subsection{Bioreactors and Operational Parameters}

Conventional anaerobic digestion systems require a long hydraulic retention time (HRT) of approximately 30-40 days, which means that they need to be modified to prevent biomass from leaching from the reactors.

Distillery stillage has been treated in various types of anaerobic digesters, including a sequencing batch reactor (ASBR), an up-flow anaerobic sludge blanket reactor (UASB), an anaerobic continuous stirred tank reactor (CSTR), an anaerobic baffled reactor (ABR), a down-flow stationary fixed film (DSFF), and an anaerobic membrane bioreactor (AnMBR), with COD removal ranging from 82 to $99 \%$ and an organic loading rate (OLR) ranging from 2.9 to $29 \mathrm{~kg} \mathrm{COD} /\left(\mathrm{m}^{3} \cdot \mathrm{d}\right)$ [30-37]. Anaerobic digestion technologies and operational conditions of reactors are presented in Table 2. 
Table 2. Technologies of anaerobic digestion of distillery stillage.

\begin{tabular}{|c|c|c|c|c|c|}
\hline $\begin{array}{l}\text { Anaerobic Digestion } \\
\text { Technology }\end{array}$ & Organic Loading Rate & $\begin{array}{l}\text { Hydraulic Retention } \\
\text { Time (Days) }\end{array}$ & Biogas Yield & Methane Yield & References \\
\hline CSTR & $1.6-3.5 \mathrm{~g} \mathrm{VS} /(\mathrm{L} \cdot \mathrm{d})$ & $25-40$ & $1.67-2.39 \mathrm{~L} /(\mathrm{L} \cdot \mathrm{d})$ & $\begin{array}{l}0.45-1.41 \mathrm{~L} \mathrm{CH}_{4} /(\mathrm{L} \cdot \mathrm{d}) \\
0.12-0.63 \mathrm{~L} \mathrm{CH}_{4} / \mathrm{g} \text { VS }\end{array}$ & [31] \\
\hline CSTR & $3.2-7.6 \mathrm{~g} \mathrm{COD} /(\mathrm{L} \cdot \mathrm{d})$ & $12-30$ & - & $0.46-0.62 \mathrm{~L} \mathrm{CH}_{4} / \mathrm{g}$ VS & [32] \\
\hline AFBR & $29 \mathrm{~kg} \mathrm{COD} /\left(\mathrm{m}^{3} \cdot \mathrm{d}\right)$ & 3.5 & $15.8 \mathrm{~L} /(\mathrm{L} \cdot \mathrm{d})$ & $160 \mathrm{~L} \mathrm{CH}_{4} / \mathrm{d}$ & [34] \\
\hline $\begin{array}{c}\text { Conventional } \\
\text { ABRHybrid ABR }\end{array}$ & $\begin{array}{l}1.1-1.8 \mathrm{~kg} \mathrm{COD} /\left(\mathrm{m}^{3} \cdot \mathrm{d}\right) \\
1.0-3.5 \mathrm{~kg} \mathrm{COD} /\left(\mathrm{m}^{3} \cdot \mathrm{d}\right)\end{array}$ & $4.2-11.0$ & - & $\begin{array}{l}0.14-0.24 \mathrm{~L} \mathrm{CH}_{4} / \mathrm{g} \text { COD } \\
0.29-0.31 \mathrm{~L} \mathrm{CH}_{4} / \mathrm{g} \text { COD }\end{array}$ & [35] \\
\hline DSFF & $1.2-11.6 \mathrm{~g} \mathrm{COD} /(\mathrm{L} \cdot \mathrm{d})$ & $4.2-20.0$ & $0.7-3.8 \mathrm{~L} / \mathrm{d}$ & $0.43-2.05 \mathrm{~L} \mathrm{CH}_{4} /(\mathrm{L} \cdot \mathrm{d})$ & [36] \\
\hline AnMBRs & $6.1-8.3 \mathrm{~kg} \mathrm{COD} /\left(\mathrm{m}^{3} \cdot \mathrm{d}\right)$ & $10-12$ & - & $\begin{array}{c}16.9-22.6 \mathrm{~L} / \mathrm{d} \\
0.26-0.29 \mathrm{~L} \mathrm{CH}_{4} / \mathrm{kg} \mathrm{COD}\end{array}$ & [37] \\
\hline
\end{tabular}

As an example, the ASBR allowed a soluble COD removal efficiency greater than $98 \%$ to be obtained at an OLR of $8.6 \mathrm{~kg} \mathrm{COD} /\left(\mathrm{m}^{3} \cdot \mathrm{d}\right)$ at an HRT of 2.2 days [30]. Melamane et al. [38] reported the application of the down-flow fluidization technology for the anaerobic digestion of distillery stillage, in which $85 \%$ total organic carbon (TOC) removal was achieved at an OLR of $4.5 \mathrm{~kg} \mathrm{TOC} /\left(\mathrm{m}^{3} \cdot \mathrm{d}\right)$. However, UASB reactors are the most used high-rate digesters for anaerobic treatment of various types of industrial wastewaters. In a UASB treating distillery wastewater, COD removal efficiency of over $90 \%$ was reported [39]. In another anaerobic treatment method, fluidized bed reactors contained appropriate media, such as sand, gravel, or plastics, for bacterial attachment and growth A two-stage process with an anaerobic filter, followed by a UASB reactor was investigated by Blonskaja et al. [40]. The acidogenic and methanogenic phases were separated, ensuring better conditions for the methanogens. COD removal was 54 and $93 \%$ in these stages, respectively. In general, such two-stage systems were found to enable better conditions for the methanogenic phase, thus being more suitable for anaerobic digestion of distillery waste [41].

In the conventional CSTR systems, the purpose of anaerobic digestion is to maintain the stable process conditions, along with shortening the HRT, because this allows conversion of a higher amount of distillery stillage to energy. Lee et al. [31] examined the shortening HRT in a CSTR during the anaerobic digestion of distillery stillage obtained at corn ethanol production. The results showed no differences in volatile solid (VS) reduction $(82-83 \%)$ in the reactor, with HRTs ranging from 25 to 40 days. The maximum rate of the methane production of $1.41 \mathrm{~L} \mathrm{CH}_{4} /(\mathrm{L} \cdot \mathrm{d})$ was produced at 25-day HRT, whereas the maximum methane yield of approximately $0.63 \mathrm{~L} \mathrm{CH}_{4} / \mathrm{g}$ VS was achieved at HRTs between 30 and 40 days. Simulation results using a kinetic model indicated that the reactor needs to be operated for longer than 23 days to achieve $80 \%$ of the maximum methane yield.

The increase in process efficiency in the conventional CSTRs can be achieved by increasing the temperature, which also leads to shortening the HRT. Anaerobic digestion of corn ethanol thin stillage was tested at thermophilic temperature $\left(55^{\circ} \mathrm{C}\right)$ in two CSTRs. The thin stillage was organically concentrated with $100 \mathrm{~g} \mathrm{COD}_{\text {tot }} / \mathrm{L}$ and $60 \mathrm{~g} \mathrm{VS} / \mathrm{L}$ and a low $\mathrm{pH}$ of approximately 4.0. Steady-state conditions were achieved at 30-, 20-, and 15-day HRTs, and digester failure was obtained at a 12-day HRT. A significant reduction in VS was achieved, with a maximum reduction (89.8\%) at the 20-day HRT. Methane yield ranged from 0.6 to $0.7 \mathrm{~L} \mathrm{CH}_{4} / \mathrm{g}$ VS removed during steady-state operation. Effluent VFAs below $200 \mathrm{mg} / \mathrm{L}$ as acetic acid were achieved at 20- and 30-day HRTs [32]. Oosterkamp et al. [33] managed to shorten HRT to 10 days treating distillery stillage in the CSTR also under thermophilic $\left(55^{\circ} \mathrm{C}\right)$ conditions. The methane production was $0.43 \mathrm{~L} \mathrm{CH}_{4} /(\mathrm{g} \mathrm{COD} \cdot \mathrm{d})$, COD removal was $64 \%$, soluble COD removal was $62 \%$, and $\mathrm{pH}$ was 7.7 .

Operating at a high OLR $\left(>25 \mathrm{~kg} \mathrm{COD} /\left(\mathrm{m}^{3} \cdot \mathrm{d}\right)\right)$ and short HRT (less than 5 days) is possible when the micro-organisms are retained inside the reactor. Andalib et al. [34] tested the anaerobic fluidized bed bioreactor (AFBR) employing zeolite with an average diameter $(\mathrm{dm})$ of $425-610 \mu \mathrm{m}$ and a specific surface area of the carrier media of $26.5 \mathrm{~m}^{2} / \mathrm{g}$. 
Despite a very high concentration of distillery stillage with COD of $130 \mathrm{~g}$ COD/L and total suspended solids (TSS) of $47 \mathrm{~g} / \mathrm{L}$, the AFBR showed up to $88 \%$ COD and $78 \%$ TSS removal at a very high OLR of $29 \mathrm{~kg} \mathrm{COD} /\left(\mathrm{m}^{3} \cdot \mathrm{d}\right)$ and HRT of 3.5 days. Methane production rates of up to $160 \mathrm{~L} / \mathrm{d}$ at the steady-state equivalent to $40 \mathrm{~L} \mathrm{CH}_{4} / \mathrm{L}$ distillery stillage and biogas production rate per reactor volume of $15.8 \mathrm{~L} /(\mathrm{L} \cdot \mathrm{d})$ were achieved.

The reduction in biomass washout, higher solid retention time (SRT), and significantly improved phase separation can be achieved in the hybrid configuration of an anaerobic baffled reactor (ABR) where solid/liquid/gas separators were incorporated into the configuration of the conventional ABR [35]. The hybrid ABR achieved higher COD removal, sulfate removal, and methane yield of 97-94\%, 94-97\%, and 294-310 $\mathrm{mL} \mathrm{CH}_{4} / \mathrm{g} \mathrm{COD,}$ respectively, at an OLR of $1.0-3.5 \mathrm{~kg} \mathrm{COD} /\left(\mathrm{m}^{3} \cdot \mathrm{d}\right)$ than conventional ABR, where $75-94 \%$ COD removal, 67-76\% sulfate removal, and 140-240 $\mathrm{mL} \mathrm{CH}_{4} / \mathrm{g}$ COD were obtained at an OLR range of $1.1-1.8 \mathrm{~kg} \mathrm{COD} /\left(\mathrm{m}^{3} \cdot \mathrm{d}\right)$.

Thin stillage from a dry-grind corn ethanol plant was evaluated as a carbon source for anaerobic digestion by batch and high-rate semi-continuous down-flow stationary fixed film (DSFF) reactors. Continuous studies employed two mesophilic DSFF anaerobic digesters treating thin stillage operated at HRTs of 20.0, 14.3, 8.7, 6.3, 5.0, and $4.2 \mathrm{~d}$. Successful digestion was achieved up to an OLR of approximately $7.4 \mathrm{~g} \mathrm{COD} /(\mathrm{L} \cdot \mathrm{d})$ at an HRT of $5 \mathrm{~d}$, with a yield of $2.05 \mathrm{~L} \mathrm{CH}_{4} /(\mathrm{L} \cdot \mathrm{d})$ and $\mathrm{COD}_{\text {tot, }}$, and VS removal efficiencies of $89 \%$ and $85 \%$, respectively [36].

Besides the operational conditions, lipids in the lipid-rich distillery stillage cause operational problems in anaerobic digesters due to clogging and mass transfer problems because they are adsorbed to the microbial biomass surface. The flotation of biomass due to adhesion of fat may cause loss of active biomass because of washout. An excellent solution to biomass washout problems was reported for the treatment of lipid-rich wastewater in granular sludge bed reactors. The potential of anaerobic membrane bioreactors (AnMBRs) for the treatment of lipid-rich corn-to-ethanol thin stillage was investigated by Dereli et al. [37] at three different SRTs of 20, 30, and 50 days. The AnMBRs achieved up to $99 \%$ COD removal efficiencies and excellent effluent quality. Although higher OLRs up to $8.0 \mathrm{~kg} \mathrm{COD} /\left(\mathrm{m}^{3} \cdot \mathrm{d}\right)$ could be applied in the reactors operated at shorter SRTs, better biological degradation efficiencies, i.e., up to $83 \%$, were achieved at increased SRTs. Severe long-chain fatty acid (LCFA) inhibition was observed at 50-day SRT, possibly caused by the extensive dissolution of LCFA in the reactor, inhibiting the methanogenic biomass.

Maintaining stable anaerobic digestion, despite the rapid acidification and accumulation of intermediate VFAs lowering microbial activity and biomethane production, can be challenging. Therefore, more research is focused on how to recover anaerobic digestion performance after acidic shock ( $\mathrm{pH}$ 5.5). The carbonaceous materials may function as an abiotic conductive conduit to stimulate microbial electron transfer and resist adverse effects on anaerobic digestion. Wu et al. [42] tested the nanomaterial graphene and more cost-effective pyrochar in their ability to recover anaerobic digestion performance after acidic shock ( $\mathrm{pH}$ 5.5). Results showed that graphene addition $(1.0 \mathrm{~g} / \mathrm{L})$ could lead to a biomethane yield of $250 \mathrm{~mL} / \mathrm{g}$ COD; this was an $11 \%$ increase compared to the control. The recovered process was accompanied by faster propionate degradation $\left(\mathrm{CH}_{3} \mathrm{CH}_{2} \mathrm{COO}^{-}+2 \mathrm{H}_{2} \mathrm{O} \rightarrow \mathrm{CH}_{3} \mathrm{COO}^{-}+\mathrm{CO}_{2}+6 \mathrm{H}^{+}+6 \mathrm{e}^{-}\right)$. The enhanced performance was possibly ascribed to the high electrical conductivity of graphene. In comparison, pyrochar addition ( 1 and $10 \mathrm{~g} / \mathrm{L}$ ) did not enhance the biomethane yield, though it reduced the digestion lag-phase time by 18.1 and $12.2 \%$ compared to the control, respectively. Microbial taxonomy analysis suggested that Methanosarcina (81.5\% in abundance) with diverse metabolic pathways and OTU in the order DTU014 (6.4\% in abundance) might participate in direct interspecies electron transfer, contributing to an effective recovery from acidic shock. 


\subsection{Effect of Polyphenols and Melanoidin on Biomethane Production}

It was reported that distillery waste contains recalcitrant compounds, namely polyphenols and melanoidins, which exhibit toxicity towards micro-organisms [11,43,44]. Although the concentrations of polyphenols in some distillery wastes (molasses distillery wastewater) are more than two times lower [12] and they contribute less to the antimicrobial effect, at the same concentrations, polyphenols have a higher antimicrobial effect than melanoidins [11]. Figure 2 shows the structure of common polyphenols and melanoidins that are found in the distillery stillage.

Polyphenols are the compounds that particularly adversely affect methanogenesis, thus inhibiting the ability of methanogens to produce biofuels. According to Fedorak and Hrudey [45], this inhibition is visible at polyphenol concentrations above $1 \mathrm{~g} / \mathrm{L}$. The concentrations of phenolic compounds above $1 \mathrm{~g} / \mathrm{L}$ decreased the biogas production from waste by $10 \%$, and concentrations increased to $1.5,2.0$, and $4.0 \mathrm{~g} / \mathrm{L}$ reduced the production by 29,78 , and $98 \%$, respectively [46]. In other studies on anaerobic digestion, biogas production was decreased by phenol concentrations above $0.8 \mathrm{~g} / \mathrm{L}$ [47]. On the other hand, at concentrations $120-594 \mathrm{mg} / \mathrm{L}$, biogas production was decreased by up to $50 \%$, depending on the polarity, type, molecular size, and amount of the phenolic compounds [48]. Melanoidins account for over $2 \%(\mathrm{~m} / \mathrm{v})$ of molasses distillery wastewater composition [49]. Although the toxicity of melanoidins is lower, under anaerobic conditions, its brown color is intensified [50], which impedes decolorization of the effluents.

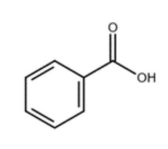

pOH-benzoic<smiles>COc1cc(C(=O)O)ccc1O</smiles>

vanilic<smiles>CCCOc1cc(C(=O)CC)cc(CC)c1O</smiles>

syringic<smiles>O=C(O)/C=C/c1ccc(O)cc1</smiles>

p-cumaric<smiles>COc1cc(/C=C/C(=O)O)cc(OC)c1O</smiles>

ferulic

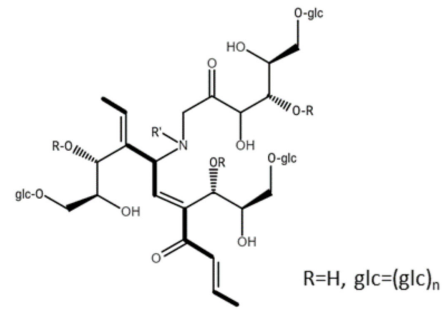

glycine-glucose melanoidin

Figure 2. The structure of polyphenols and melanoidin (based on [51]) typical for the distillery stillage.

To improve biomethane production and to ensure the profitability of biogas plants, technologies for accelerating biomethane production from wastes that contain polyphenols should be developed. The antioxidative properties of polyphenols and melanoidins made them important for food, cosmetics, and pharmaceutical applications. Therefore, their recovery from distillery waste can bring two advantages: obtaining products of commercial interest and improving anaerobic digestion of this waste. For example, Kaushik et al. [52] used ultrafiltration, adsorption-desorption, and solvent extraction for recovering polyphenols and melanoidins from sugarcane molasses distillery wastewater. Methane content in produced biogas increased from $51 \%$ in the control sample to $70 \%$ after adsorption, which improved the methanation the most from the tested options. From molasses distillery effluents, melanoidins were removed with biological and physicochemical methods, as well as employing microbial fuel cells for electricity generation [53]. Biological methods included the use of a pure bacterial consortium comprising Proteus mirabilis, Bacillus sp., Raoultella planticola, and Enterobacter sakazakii [49], or phycoremediation [7]. Physicochemical 
methods included electrochemical degradation performed with ruthenium-oxide-coated titanium mesh (anode) and stainless steel (cathode) [54], or UV photodegradation [55].

\subsection{Pretreatment of Distillery Stillage}

To couple with anaerobic processing of distillery stillage, pretreatment techniques were used, including ozonation, ultrasound, thermal process, hydrodynamic cavitation, and fungal pretreatment. Methane yield coefficient and methane production rate were increased by about $13.6 \%$ and $41.16 \%$, respectively, when using ozonation [56]. This pretreatment did not increase COD removal itself compared to anaerobic digestion alone; however, it converted polyphenols to other forms, thus increasing methanogenesis efficiency [56]. Hydrodynamic cavitation removed COD by $32.24 \%$, TOC by $31.43 \%$, and color by $48.00 \%$ [57]. Thermal pretreatment, ultrasound, and ozonation resulted in a $45.6 \%$ reduction in COD [58]. Fungal pretreatment with Trametes pubescens resulted in 53.3 and $72.5 \%$ removal of COD and polyphenols, respectively [59].

\subsection{Post-Treatment of Distillery Stillage}

To valorize distillery wastes, anaerobic digestion is mostly used to recover energy in the form of biogas. However, the effluent from anaerobic digestion still contains organic compounds and is dark in color. As an example, anaerobically digested stillage may contain 25,000-40,000 mg COD/L, 7000-10,000 mg BOD/L, and 22,000-34,000 mg TSS/L [7]. It was found that anaerobic processing does not decrease polyphenol content [11]. In addition, some polyphenols may be transformed from one form to another during different phases of the fermentation process [60], and, also, the transformation of polyphenols to less colored but more toxic products can proceed during the treatment of distillery waste with fungus Pleurotus sp. under aerobic conditions [61]. Therefore, to meet the environmental discharge standards, further treatment is necessary. Most often, when the BOD/COD ratio of the anaerobic effluent is greater than 0.25 , the effluent is treated aerobically.

In the development of biological methods, the ability of some microbial strains or consortia to biodegrade anaerobically digested distillery stillage was examined. Efficient biodegradation was obtained when using such bacterial genera as Pseudomonas, Bacillus, Microbacterium, Achromobacter, Staphylococcus, and Alcaligenes [62,63]. According to Mohana et al. [64], Pseudomonas, Stenotrophomonas, and Proteus were able to remove COD $(51 \%)$ and color $(67 \%)$ within $72 \mathrm{~h}$. The decolorization was possible by excretion of manganese peroxidase and laccase that removed the melanoidin by over 70\% [49]. Removal of color was also achieved when employing yeast strains for the post-treatment of molasses distillery wastewater [65]; the removal efficiencies of color, COD, and BOD by Citeromyces sp. were 75 , almost 100 , and $76 \%$, respectively. From the same type of wastewater, extracellular enzymes secreted by white-rot fungi (manganese peroxidase, lignin peroxidase, and phenol oxidase (laccase)) allowed efficient removal of melanoidin and polyphenols [66].

Apart from pure cultures, mixed cultures of activated sludge were reported to efficiently remove tannic acid polyphenol-containing wastewater under aerobic conditions at dissolved oxygen concentrations above $1 \mathrm{mg} / \mathrm{L}$ [67]. To enhance microbial growth and improve polyphenol degradation, supplementation of carbon sources was carried out [68]. The studies of aerobic treatment of anaerobically digested distillery stillage focused on the optimization of the operating parameters, particularly OLR. In the sequencing batch reactor (SBR) operated at a constant HRT of $24 \mathrm{~h}$, an increase in OLR from 1.8 to $9 \mathrm{~kg} \mathrm{COD} /\left(\mathrm{m}^{3} \cdot \mathrm{d}\right)$ decreased the SBR performance [69]. The highest removal of COD $(74 \%)$ and BOD $(96 \%)$ was obtained at $3.6 \mathrm{~kg} \mathrm{COD} /\left(\mathrm{m}^{3} \cdot \mathrm{d}\right)$. Apart from activated sludge reactors, biofilm in a rotating biological contactor was used after treating distillery stillage in microbial fuel cells [70]. The removal of COD and BOD was 84 and $81 \%$, respectively.

The combination of activated sludge treatment with a biomass separation on a membrane in the technology of membrane bioreactors (MBR) results in a recovery of high-quality effluent when treating distillery stillage, a smaller footprint, and reduced sludge generation. In a lab-scale MBR, 95\% COD reduction and 92\% decolorization were achieved [71]. 
At an OLR between 3.0 and $5.7 \mathrm{~kg} \mathrm{COD} /\left(\mathrm{m}^{3} \cdot \mathrm{d}\right), 41 \%$ COD removal [5] or $60 \%$ COD removal [72] was obtained, depending on the cut-off of the membrane used. In the study by Deschamps et al. [73], the membrane was directly incorporated into the anaerobic treatment, which produced a pilot-scale AnMBR. High biogas production of $1.36 \mathrm{NL}_{\text {biogas }} /\left(\mathrm{L}_{\text {bioreactor }} \cdot \mathrm{d}\right)$ was obtained at an OLR of $3.97 \mathrm{~kg} \mathrm{COD} /\left(\mathrm{m}^{3} \cdot \mathrm{d}\right)$ and HRT of $3.5 \mathrm{~d}$. By comparison, with the anaerobic packed-bed bioreactor, it was found that the higher COD removal efficiency (96.9\%) and higher methane production $\left(0.26 \mathrm{~L} \mathrm{CH}_{4} / \mathrm{g} \mathrm{COD}\right)$ were obtained in the AnMBR with a shorter start-up period (21 d).

The limitations of aerobic processes for post-treatment of distillery stillage include the energy costs for aeration, high amount of excess sludge produced, necessity of nutrient supplementation, and operation at high dilution rates [11]. To make the post-treatment more energetically efficient, phycoremediation using microalgae was applied [7]. Particularly, effluents from the acidogenic process can be used by these photosynthetic organisms, also termed photobiocapture organisms. In this process, microalgae use nutrients present in the effluent and sunlight for growth. Moreover, carbon dioxide is absorbed by microalgae and converted into oxygen, thus reducing the energy requirements. Biomass produced may be further utilized for the production of biogas, biodiesel, or fertilizer. However, the feasibility of this technology depends on sufficient sunlight accessibility in a particular location. As an example, $83.2 \%$ of COD and $88.0 \%$ of BOD were removed in microalgae ponds with an HRT of $11 \mathrm{~d}$ [74].

For post-treatment, physicochemical methods are also used; however, they are more effective for low-loaded effluents than biological processes. To recycle the water, reverse osmosis allowed for recovering $60 \%$ of water, with a permeate COD of $100 \mathrm{mg} / \mathrm{L}$ [7]. However, a high-pressure drop on the membrane under the conditions of high pollutant load and the necessity to utilize retentate increase the total operational cost.

The other solution that allows for water recovery from distillery thin stillage is evaporation that increases the solid content to 55-60\% [75]. Burning stillage generates steam, which can be used as evaporation fuel, to generate electricity or run a turbine. The condensate from the evaporation system can be recycled back to the fermentation process. However, the process is highly energy-intensive; $550 \mathrm{kcal}$ of energy is required to evaporate $1 \mathrm{~L}$ of water [7].

The other post-treatment process used is ultraviolet (UV) photodegradation. In the study by Apollo et al. [55], it was found that UV photodegradation is effective in color removal, but not effective in COD and BOD removal from distillery effluent. On the other hand, anaerobic digestion alone removed COD effectively, but the color was not sufficiently removed, or even increased because of the conversion of color imparting compounds, such as melanoidin. Therefore, using UV photodegradation as a post-treatment to the anaerobic digestion allowed COD removal of above $85 \%$ and $88 \%$ of color removal to be obtained.

\section{Processing of Distillery Stillage-Bioethanol Production}

Due to the excess of distillery stillage on the market, it becomes necessary to develop an alternative concept of its management. Due to the high content of the polysaccharide fraction in the distillery stillage, low price, and widespread availability, an interesting direction is its use as a raw material source to produce second-generation ethanol (Figure 3).

The whole stillage includes the liquid remaining after distilling ethanol, containing, depending on the technology used, from 7 to $20 \%$ of dry weight (DW). It consists mainly of fiber, protein, fat, unhydrolyzed starch, and dead yeast cells. The biological transformation of the distillery stillage must be preceded by the depolymerization of hemicellulose and cellulose, leading to the obtaining of a liquid fraction of products rich in fermentable monosaccharides. However, the factor that limits the biotransformation of the distillery stillage to the second-generation ethanol is the presence of undesirable components in the hydrolysate, in particular, 2-furfural and 5-hydroxymethylfurfural. The presence of furfurals, byproducts of polysaccharide depolymerization, adversely affects the development of yeast, inhibiting or even stopping the alcohol fermentation of the remaining ingredients 
of the hydrolyzed distillery stillage. The examples of ethanol production from distillery stillage are presented in Table 3.

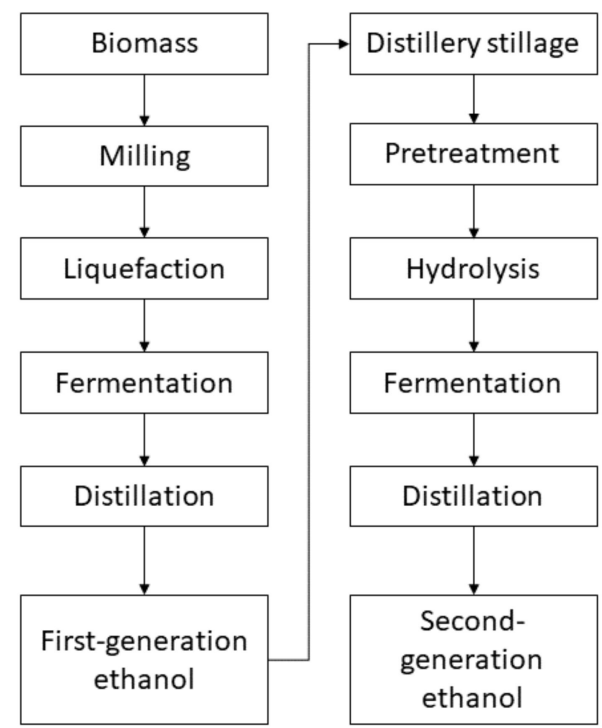

Figure 3. First- and second-generation ethanol production.

Table 3. The efficiency of the ethanol fermentation process using stillage.

\begin{tabular}{cccc}
\hline Type of Stillage & Ethanol Production & \% of Theoretical Yield & References \\
\hline Corn grain & $60.97 \mathrm{~L} / \mathrm{kg}$ starch & 84.80 & {$[76]$} \\
\hline Maize & $70.65 \%$ of starch & 98.76 & {$[77]$} \\
\hline Winter triticale BOGO & $68.87 \mathrm{~L} / \mathrm{kg}$ starch & 95.78 & {$[78]$} \\
\hline
\end{tabular}

Conversion of the hemicellulose and cellulose to fermentable sugars, and then to ethanol has the potential to significantly increase the efficiency of the process. Mikulski and Kłosowski [79] evaluated the effectiveness of various parameters of low-temperature pretreatment with dilute sulfuric acid $\left(121\right.$ or $131^{\circ} \mathrm{C}, 30$ or $60 \mathrm{~min}, 0.1$ or $0.2 \mathrm{M} \mathrm{H}_{2} \mathrm{SO}_{4}$ ) for production of cellulosic ethanol. Optimal conditions for dilute acid pretreatment of rye and wheat distillery stillage were $121^{\circ} \mathrm{C}, 0.2 \mathrm{M} \mathrm{H}_{2} \mathrm{SO}_{4}$, and $60 \mathrm{~min}$, whereas those of maize stillage were $131^{\circ} \mathrm{C}, 0.2 \mathrm{M} \mathrm{H}_{2} \mathrm{SO}_{4}$, and $60 \mathrm{~min}$. The highest efficiency of enzymatic hydrolysis was achieved for rye and wheat stillage using $1 \mathrm{~g}$ DW and the concentration of cellulolytic enzyme of $24 \% w / w$, and, for maize stillage, $3 \mathrm{~g}$ DW and enzyme concentration of $24 \% \mathrm{w} / \mathrm{w}$. The use of rye and wheat stillage for the production of ethanol did not require a detoxification process and enabled full attenuation of glucose after $48 \mathrm{~h}$ of the process. However, the use of maize stillage as a raw material must be preceded by a detoxification process to reduce 5-hydroxymethylfurfural concentration in the fermentation medium.

To increase the pretreatment efficiency of bioethanol production, microwaves can be used. Mikulski et al. [21] tested the microwave-assisted pretreatment method of distillery stillage in the production of cellulosic bioethanol from maize distillery stillage. High glucose concentration (104.4 mg/g DW) and the highest yield of enzymatic cellulose hydrolysis (75.8\%) were obtained for microwave pretreatment (300 W, 54 PSI, $15 \mathrm{~min}$ ). These conditions allowed not only a high concentration of glucose to be obtained, but also a low concentration of fermentation inhibitors, i.e., 5-hydroxymethylfurfural $(6.8 \mathrm{mg} / \mathrm{g}$ DW) and furfural ( $6.0 \mathrm{mg} / \mathrm{g}$ DW). The optimal dose of yeast, Saccharomyces cerevisiae strain Ethanol Red, which gave a high attenuation, was $2 \mathrm{~g} / \mathrm{L}$ of cellulose fermentation medium. Detoxification of cellulose hydrolysates with activated carbon enabled a high fermentation yield (approximately $77 \%$ of the theoretical yield) to be achieved. Microwave processing can be an effective pretreatment method in the production of cellulosic ethanol from maize 
distillery stillage, but this process requires a careful selection of parameters. The same research group proposed the hydrotropic delignification using sodium cumene sulfonate for pretreatment of rye, wheat, and maize stillage in the production of bioethanol. The highest stillage biomass extractives were obtained for a biomass particle size $<1.0 \mathrm{~mm}$ when exposed to $131^{\circ} \mathrm{C}$ for $1 \mathrm{~h}$ at $20 \% v / v$ hydrotrope concentration. It has been shown that hydrotropic treatment causes changes in the stillage biomass structure (increase in porosity) and reduces the lignin content in biomass by $7-17 \%$. Delignification with a hydrotrope also increased the concentration of fermentable sugars in the media prepared with stillage biomass, which led to a higher final ethanol concentration (up to ca. $3.5 \mathrm{~g} / \mathrm{L}$ ). Hydrotropic treatment is an effective way of pretreating stillage biomass. It provides a high degree of biomass bioconversion and creates the prospect of integrating the first- and secondgeneration ethanol production process to utilize the raw material more fully [80].

The hydrolysis of distillery stillage to fermentable sugars was optimized using $2 \%(v / v)$ $\mathrm{H}_{2} \mathrm{SO}_{4}$ at $100{ }^{\circ} \mathrm{C}$ for $5.5 \mathrm{~h}$ and produced $18 \mathrm{~g} / \mathrm{L}$ xylose, $11.5 \mathrm{~g} / \mathrm{L}$ arabinose, and $6.5 \mathrm{~g} / \mathrm{L}$ glucose from $120 \mathrm{~g} / \mathrm{L}$ stillage [81]. Further enzymatic hydrolysis increased the release of glucose by $61 \%$. Furfural, acetate, and lactate were the main inhibitors present in the acid hydrolysate of stillage. The lignin-derived inhibitors hydroxymethylfuraldehyde, hydroxybenzaldehyde, vanillin, and syringaldehyde were not detected. Neutralization of the hydrolysate with lime to $\mathrm{pH} 5$ decreased the concentration of furfural by $50 \%$. Fermentation of hydrolysate by recombinant Zymomonas mobilis ZM4(pZB5) supplemented with $10 \mathrm{~g} / \mathrm{L}$ of glucose produced $11 \mathrm{~g} / \mathrm{L}$ of ethanol after $70 \mathrm{~h}$, with residual xylose $12 \mathrm{~g} / \mathrm{L}$. Supplementation of the hydrolysate with $5 \mathrm{~g} / \mathrm{L}$ yeast extract and $40 \mathrm{~g} / \mathrm{L}$ of glucose produced $28 \mathrm{~g} / \mathrm{L}$ of ethanol with $2.6 \mathrm{~g} / \mathrm{L}$ residual xylose after $18 \mathrm{~h}$. Arabinose was not utilized by this recombinant strain. It could be concluded that Z. mobilis ZM4(pZB5) may be a suitable candidate for the fermentation of both glucose and xylose in stillage acid hydrolysates.

\section{Processing of Distillery Stillage-Biohydrogen Production}

In addition to the valorization of distillery stillage to biomethane and bioethanol production, the recovery of biohydrogen as a clean energy carrier seems to be a promising option. Molecular hydrogen is regarded as the most promising energy source because of its high energy content $(143 \mathrm{~kJ} / \mathrm{g})$ and lack of $\mathrm{CO}_{2}$ emission [82]. Converting organic matter to biohydrogen can be both autotrophic (biophotolysis) and heterotrophic (dark fermentation and photofermentation). Photofermentation is conducted by purple nonsulfur bacteria [83], which use light as an energy source and organic compounds as carbon and electron sources. Dark fermentation does not require light energy and can utilize a wide variety of substrates for hydrogen production [84]. From the literature reports, it can be concluded that the composition of microbial consortia involved in the process and composition of feedstock play an important role in biohydrogen recovery from distillery effluents.

Exemplary hydrogen yields obtained from distillery waste processing are given in Table 4 . In the study by Laurinavichene et al. [85], distillery wastewater was proceeded with dark fermentation or photofermentation alone, and with sequential dark fermentation and photofermentation. Anaerobic saccharolytic consortium and purple nonsulfur bacteria were employed. Complete consumption of organic acids and sugars and the maximal $\mathrm{H}_{2}$ yield of $17.6 \mathrm{~L} / \mathrm{L}$ of distillery waste $(205 \mathrm{~kJ} / \mathrm{L}$ distillery waste) were achieved when dark and photofermentation were combined. This yield corresponded to the recovery of approximately $4-8 \%$ of the energy consumed during bioethanol production.

For biohydrogen production from distillery effluent, Mishra et al. [86] used acidogenic mixed consortia (AMC), synthetic coculture (Klebsiella pneumoniae IIT-BT 08 and Citrobacter freundii IIT-BT L139), and pure culture. Compared to the synthetic coculture and pure culture, the use of AMC resulted in the highest hydrogen yield $(9.17 \mathrm{~mol} / \mathrm{kg} \mathrm{COD}$ reduced $)$; maximum energy recovery was higher by $21.9 \%$ and $45.4 \%$ than that of coculture and pure culture, respectively. The AMC, which was predominated by species closely affiliated to Clostridium sp., gave the average hydrogen production rate of $267 \mathrm{~mL} /(\mathrm{L} \cdot \mathrm{h})$. 
Biohydrogen production via dark fermentation of distillery effluent by Enterobacter cloacae IIT-BT 08 was compared with that of cane molasses and starchy wastewater [87]. The highest maximum hydrogen yield $\left(12.2 \mathrm{~mol} \mathrm{H}_{2} / \mathrm{kg} \mathrm{COD}\right.$ removed $)$ was achieved with cane molasses and groundnut de-oiled cake as a cosubstrate. With distillery effluent, the maximum hydrogen yield was $7.4 \mathrm{~mol} \mathrm{H}_{2} / \mathrm{kg} \mathrm{COD}_{\text {removed }}$ ).

Table 4. Hydrogen yields from distillery waste.

\begin{tabular}{ccc}
\hline Organics in the Substrate (g COD/L) & Hydrogen Yield & References \\
\hline 40.0 & $17.6 \mathrm{~L} / \mathrm{L}$ of distillery waste & {$[85]$} \\
\hline 38.0 & $9.17 \mathrm{~mol} / \mathrm{kg}$ COD $_{\text {reduced }}$ & {$[86]$} \\
\hline 52.0 & $12.2 \mathrm{~mol} / \mathrm{kg} \mathrm{COD}$ removed & {$[87]$} \\
\hline 40.0 & $172 \mathrm{~mL} / \mathrm{g} \mathrm{COD}$ removed & {$[88]$} \\
\hline 30.6 & $8.24 \mathrm{~mL} / \mathrm{g} \mathrm{COD}$ & {$[89]$} \\
\hline 125.0 & $44.28 \mathrm{~mL} / \mathrm{g}$ COD & {$[90]$} \\
\hline 60.0 & $464 \mathrm{~mL} / \mathrm{g}$ carbohydrate & {$[91]$} \\
\hline 16.3 & $0.47 \mathrm{~mol} / \mathrm{mol}$ carbohydrate & {$[92]$} \\
\hline
\end{tabular}

\section{Bioelectrochemical-Based Systems}

Bioelectrochemical-based treatment is considered the most employed process in distillery wastewater treatment [93]. In bioelectrochemical processes, the chemical energy stored in biodegradable organic materials is converted to electrical current using the catalytic activity of micro-organisms. In the process termed bioelectrogenesis, protons and electrons produced in the acidogenesis can be harvested as electrical energy in the presence of an electrode assembly in a microbial fuel cell (MFC). MFCs can be applied for producing biofuels. MFCs employ electrochemically active bacteria to catalyze the oxidation of electron donors in the anodic chamber and deliver electrons to the cathode. These electrons are captured directly for the generation of bioelectricity.

The power generation in bioelectrochemical systems for distillery waste processing can vary widely (Table 5). As examples, in the MFC, with an influent COD concentration of $6.1 \mathrm{~g} / \mathrm{L}, 64.0 \%$ of $\mathrm{COD}$ and $61.2 \%$ of $\mathrm{BOD}_{5}$ were removed, with an average current of $0.27 \mathrm{~mA}$ and power density of $18.35 \mathrm{~mW} / \mathrm{m}^{2}$ [70]. In the other study, $57 \%$ of COD and $36 \%$ of melanoidin were removed, with an average current of $5.40 \mathrm{~mA}$ [94].

When treating distillery effluents in the MFC systems, $\mathrm{pH}$ of the feed was considered one of the factors affecting the COD removal. At a pH of 8, COD removal was 63.5\% [95], whereas at a $\mathrm{pH}$ of $6, \mathrm{COD}$ removal was $72.84 \%$ [96].

The concentration of organic compounds significantly affects the performance of the MFC. With the COD concentration in distillery wastewater increasing from 3.2 to $9.6 \mathrm{~g} / \mathrm{L}$, an increase in power generation from 168 to $429 \mathrm{~mW} / \mathrm{m}^{2}$ was obtained [97]. However, the complex chemical composition of distillery effluent was considered as limiting power output, cation transport across the proton exchange membrane, and COD removal in the MFC, because it did not support the growth of electrochemically active bacterial community [98]. To confirm this thesis, Nayak et al. [53] reported that a proper dilution of distillery stillage with sewage wastewater may improve remediation and energy production. The authors used the cathodic compartment filled with microalgae Scenedesmus abundans. $\mathrm{CO}_{2}$ generated during degradation of organic substrates by anaerobic consortia was utilized by Scenedesmus abundans for photosynthesis. At a mixing ratio of distillery stillage and sewage wastewater of 50:50, up to $78.66 \%$ of COD removal, $39.66 \%$ of total dissolved solids (TDS), and removal of $97 \%$ of TSS were obtained. 
Table 5. Power generation in processing from distillery waste in bioelectrochemical-based systems.

\begin{tabular}{ccc}
\hline COD Removal (\%) & Power Density $\left(\mathbf{m W} / \mathbf{m}^{2}\right)$ & References \\
\hline 63.5 & 202.00 & {$[95]$} \\
\hline 67.5 & 429.00 & {$[97]$} \\
\hline 58.0 & 364.00 & {$[98]$} \\
\hline 43.0 & 597.00 & {$[99]$} \\
\hline 64.4 & 267.77 & {$[100]$} \\
\hline $69.0-98.0$ & $36.80-72.90$ & {$[101]$} \\
\hline 62.5 & 437.13 & {$[102]$} \\
\hline $58.4-88.4$ & 124.03 & {$[103]$} \\
\hline $66.0-78.0$ & 836.81 & {$[53]$} \\
\hline 64.0 & 18.35 & {$[70]$} \\
\hline
\end{tabular}

Currently, the most intensive development of bioelectrochemical processes relies on searching for modifications of the elements of the MFC system that allow for improving power generation. The studies were conducted to optimize the area of the proton exchange membrane [95], the number of anodic and cathodic compartments separated by the proton exchange membrane $[97,99]$, or the material from which anode or cathode is produced. Sonawane et al. [98] tested an anode made of interlacing carbon yarn with stainless steel and arranged in a double-air cathode MFC configuration. Mohanakrishna et al. [100] tested a carbon-based anode impregnated with multi-walled nanotubes and nanopowder. Prasad and Srivastava [54] used a catalytic anode modified with ruthenium oxide. In the study by Lin et al. [101], employing cell-immobilization technology for treating distillery wastewater $(3.6 \mathrm{~g} \mathrm{COD} / \mathrm{L})$ increased COD removal by $98 \%$ and power production 2.6 times in comparison to the control MFC.

\section{Conclusions and Future Directions}

Due to the increased number of distilleries and the huge amount of distillery waste that is produced, valorization of this waste is still gaining interest. Distillery waste is one of the most polluting waste products because of its low $\mathrm{pH}$, high temperature, dark brown color, and high organic content.

The most popular method for valorizing distillery stillage is biomethane production. However, optimization of the operating conditions is still necessary due to the instability of anaerobic digestion, particularly during mono-fermentation of distillery stillage. To increase process stability, additives can be supplemented to the reactor. In this regard, further studies on the use of graphene and pyrochar for improving process stability are of interest. In addition, to intensify energy production, post-treatment of anaerobically treated distillery stillage should be investigated.

In the future, more studies should focus on biohydrogen production because it is a more calorific energy source than biomethane. What seems to be most needed in this area are investigations of both nutritional supplementations to improve biohydrogen yields and methods that will enable moving biohydrogen production from the lab to pilot- and full-scale.

A promising alternative for the management of distillery stillage is the production of cellulosic bioethanol (second-generation bioethanol). This approach may facilitate a closed loop of bioethanol production that does not generate distillery waste. However, there is a need to investigate the intensification of depolymerization of cellulose and hemicelluloses to increase the yield of conversion to bioethanol.

In addition, to decrease environmental footprints and energy requirements, intensive development of bioelectrochemical-based systems is fully justified. Such development 
is particularly visible in the search for new materials for cathode and anode production or modification.

Funding: This research was funded by the Faculty of Geoengineering of the University of Warmia and Mazury in Olsztyn, grant number [29.610.024-110].

Institutional Review Board Statement: Not applicable.

Informed Consent Statement: Not applicable.

Acknowledgments: Wioleta Mikucka is a recipient of a scholarship from the Programme Interdisciplinary Doctoral Studies in Bioeconomy (POWR.03.02.00-00-I034/16-00), which is funded by the European Social Fund.

Conflicts of Interest: The authors declare no conflict of interest.

\section{References}

1. Tolmasquim, M.T. Bioenergy for the future. In Proceedings of the Conference on Biofuels: “An Option for a Less Carbon-Intensive Economy", Rio de Janeiro, Brazil, 4-5 December 2007.

2. Krzywonos, M.; Cibis, E.; Miskiewicz, T.; Ryznar-Luty, A. Utilization and biodegradation of starch stillage (distillery wastewater). Electron. J. Biotechnol. 2009, 12, 6-7. [CrossRef]

3. Krzywonos, M. Forecast for transport biofuels in Poland in 2020-2030. Przemyst Chem. 2015, 1, 168-172. [CrossRef]

4. Fito, J.; Tefera, N.; van Hulle, S.W.H. Sugarcane biorefineries wastewater: Bioremediation technologies for environmental sustainability. Chem. Biol. Technol. Agric. 2019, 6, 6. [CrossRef]

5. Satyawali, Y.; Balakrishnan, M. Treatment of distillery effluent in a membrane bioreactor (MBR) equipped with mesh filter. Sep. Purif. Technol. 2008, 63, 278-286. [CrossRef]

6. Reis, C.E.R.; Rajendran, A.; Hu, B. New technologies in value addition to the thin stillage from corn-to-ethanol process. Rev. Environ. Sci. Biotechnol. 2017, 16, 175-206. [CrossRef]

7. Sankaran, K.; Premalatha, M.; Vijayasekaran, M.; Somasundaram, V.T. Distillery wastewater treatment through anaerobic digestion and phycoremediation-A green industrial approach. Renew. Sustain. Energy Rev. 2014, 37, 634-643. [CrossRef]

8. McAloon, A.; Taylor, F.; Yee, W.; Ibsen, K.; Wooley, R. Determining the Cost of Producing Ethanol from Corn Starch and Lignocellulosic Feedstocks; National Renewable Energy Lab.: Golden, CO, USA, 2000.

9. Kwiatkowski, J.R.; McAloon, A.J.; Taylor, F.; Johnston, D.B. Modeling the process and costs of fuel ethanol production by the corn dry-grind process. Ind. Crop. Prod. 2006, 23, 288-296. [CrossRef]

10. Ganesan, V.; Rosentrater, K.A.; Muthukumarappan, K. Methodology to determine soluble content in dry grind ethanol coproduct streams. Appl. Eng. Agric. 2006, 22, 899-903. [CrossRef]

11. M'Arimi, M.M.; Zhang, Y.; Götz, G.; Kiriamiti, K.H.; Geißen, S.-U. Antimicrobial colorants in molasses distillery wastewater and their removal technologies. Int. Biodeterior. Biodegrad. 2014, 87, 34-43. [CrossRef]

12. Kaushik, A.; Basu, S.; Batra, V.; Balakrishnan, M. Fractionation of sugarcane molasses distillery wastewater and evaluation of antioxidant and antimicrobial characteristics. Ind. Crop. Prod. 2018, 118, 73-80. [CrossRef]

13. Hayase, F. Recent development of 3-deoxyosone related Maillard reaction products. Food Sci. Technol. Res. 2000, 6, 79-86. [CrossRef]

14. Amit; Ghosh, U.K. An approach for phycoremediation of different wastewaters and biodiesel production using microalgae. Environ. Sci. Pollut. Res. 2018, 25, 18673-18681. [CrossRef] [PubMed]

15. Rufián-Henares, J.A.; Morales, F.J. Functional properties of melanoidins: In vitro antioxidant, antimicrobial and antihypertensive activities. Food Res. Int. 2007, 40, 995-1002. [CrossRef]

16. Stauder, M.; Papetti, A.; Mascherpa, D.; Schito, A.M.; Gazzani, G.; Pruzzo, C.; Daglia, M. Antiadhesion and antibiofilm activities of high molecular weight coffee components against Streptococcus mutans. J. Agric. Food Chem. 2010, 58, 11662-11666. [CrossRef] [PubMed]

17. Soto, M.L.; Moure, A.; Domínguez, H.; Parajó, J.C. Recovery, concentration and purification of phenolic compounds by adsorption: A review. J. Food Eng. 2011, 105, 1-27. [CrossRef]

18. Kharayat, Y. Distillery wastewater: Bioremediation approaches. J. Integr. Environ. Sci. 2012, 9, 69-91. [CrossRef]

19. Fortney, N.W.; Hanson, N.J.; Rosa, P.R.F.; Donohue, T.J.; Noguera, D.R. Diverse profile of fermentation by products from thin stillage. Front. Bioeng. Biotechnol. 2021, 9, 550. [CrossRef] [PubMed]

20. Wilkie, A.C.; Riedesel, K.J.; Owens, J.M. Stillage characterization and anaerobic treatment of ethanol stillage from conventional and cellulosic feedstocks. Biomass Bioenergy 2000, 19, 63-102. [CrossRef]

21. Mikulski, D.; Kłosowski, G.; Menka, A.; Koim-Puchowska, B. Microwave-assisted pretreatment of maize distillery stillage with the use of dilute sulfuric acid in the production of cellulosic ethanol. Bioresour. Technol. 2019, 278, 318-328. [CrossRef]

22. Tian, Z.; Mohan, G.R.; Ingram, L.; Pullammanappallil, P. Anaerobic digestion for treatment of stillage from cellulosic bioethanol production. Bioresour. Technol. 2013, 144, 387-395. [CrossRef] [PubMed] 
23. Rajagopal, R.; Massé, D.I.; Singh, G. A critical review on inhibition of anaerobic digestion process by excess ammonia. Bioresour. Technol. 2013, 143, 632-641. [CrossRef] [PubMed]

24. Schnürer, A.; Nordberg, Å. Ammonia, a selective agent for methane production by syntrophic acetate oxidation at mesophilic temperature. Water Sci. Technol. 2008, 57, 735-740. [CrossRef] [PubMed]

25. Procházka, J.; Dolejš, P.; Máca, J.; Dohányos, M. Stability and inhibition of anaerobic processes caused by insufficiency or excess of ammonia nitrogen. Appl. Microbiol. Biotechnol. 2012, 93, 439-447. [CrossRef]

26. Moestedt, J.; Nordell, E.; Schnürer, A. Comparison of operating strategies for increased biogas production from thin stillage. J. Biotechnol. 2014, 175, 22-30. [CrossRef] [PubMed]

27. Dai, X.; Hu, C.; Zhang, D.; Dai, L.; Duan, N. Impact of a high ammonia-ammonium-pH system on methane-producing archaea and sulfate-reducing bacteria in mesophilic anaerobic digestion. Bioresour. Technol. 2017, 245, 598-605. [CrossRef] [PubMed]

28. Huertas, J.K.; Quipuzco, L.; Hassanein, A.; Lansing, S. Comparing hydrogen sulfide removal efficiency in a field-scale digester using microaeration and iron filters. Energies 2020, 13, 4793. [CrossRef]

29. Erdirencelebi, D.; Kucukhemek, M. Control of hydrogen sulphide in full-scale anaerobic digesters using iron (III) chloride: Performance, origin and effects. Water SA 2018, 44, 176-183. [CrossRef]

30. Ruiz-Herrera, J.; Martínez, A.I.; Sentandreu, R. Determination of the stability of protein pools from the cell wall of fungi. Res. Microbiol. 2002, 153, 373-378. [CrossRef]

31. Lee, P.H.H.; Bae, J.; Kim, J.; Chen, W.-H. Mesophilic anaerobic digestion of corn thin stillage: A technical and energetic assessment of the corn-to-ethanol industry integrated with anaerobic digestion. J. Chem. Technol. Biotechnol. 2011, 86, 1514-1520. [CrossRef]

32. Schaefer, S.H.; Sung, S. Retooling the ethanol industry: Thermophilic anaerobic digestion of thin stillage for methane production and pollution prevention. Water Environ. Res. 2008, 80, 101-108. [CrossRef]

33. Oosterkamp, M.J.; Bauer, S.; Ibáñez, A.B.; Méndez-García, C.; Hong, P.; Cann, I.; Mackie, R.I. Identification of methanogenesis and syntrophy as important microbial metabolic processes for optimal thermophilic anaerobic digestion of energy cane thin stillage. Bioresour. Technol. Rep. 2019, 7, 100254. [CrossRef]

34. Andalib, M.; Hafez, H.; Elbeshbishy, E.; Nakhla, G.; Zhu, J. Treatment of thin stillage in a high-rate anaerobic fluidized bed bioreactor (AFBR). Bioresour. Technol. 2012, 121, 411-418. [CrossRef] [PubMed]

35. Sayedin, F.; Kermanshahi-Pour, A.; He, S. Anaerobic digestion of thin stillage of corn ethanol plant in a novel anaerobic baffled reactor. Waste Manag. 2018, 78, 541-552. [CrossRef] [PubMed]

36. Wilkinson, A.; Kennedy, K.J. Anaerobic digestion of corn ethanol thin stillage in batch and by high-rate down-flow fixed film reactors. Water Sci. Technol. 2012, 66, 1834-1841. [CrossRef] [PubMed]

37. Dereli, R.K.; van der Zee, F.P.; Heffernan, B.; Grelot, A.; van Lier, J.B. Effect of sludge retention time on the biological performance of anaerobic membrane bioreactors treating corn-to-ethanol thin stillage with high lipid content. Water Res. 2014, 49, 453-464. [CrossRef] [PubMed]

38. Melamane, X.L.; Tandlich, R.; Burgess, J.E. Treatment of wine distillery wastewater by high rate anaerobic digestion. Water Sci. Technol. 2007, 56, 9-16. [CrossRef]

39. Wolmarans, B.; de Villiers, G.H. Start-up of a UASB effluent treatment plant on distillery wastewater. Water SA 2002, 28, 63. [CrossRef]

40. Blonskaja, V.; Menert, A.; Vilu, R. Use of two-stage anaerobic treatment for distillery waste. Adv. Environ. Res. 2003, 7, 671-678. [CrossRef]

41. Cabrera-Díaz, A.; Reyes, I.P.; Merencio, D.O.; Lebrero, R.; Zaiat, M. Anaerobic digestion of sugarcane vinasse through a methanogenic UASB reactor followed by a packed bed reactor. Appl. Biochem. Biotechnol. 2017, 183, 1127-1145. [CrossRef]

42. Wu, B.; Lin, R.; Kang, X.; Deng, C.; Xia, A.; Dobson, A.D.W.; Murphy, J.D. Graphene addition to digestion of thin stillage can alleviate acidic shock and improve biomethane production. ACS Sustain. Chem. Eng. 2020, 8, 13248-13260. [CrossRef]

43. Pereira, M.C.; Oliveira, D.A.; Hill, L.E.; Zambiazi, R.C.; Borges, C.D.; Vizzotto, M.; Mertens-Talcott, S.; Talcott, S.; Gomes, C.L. Effect of nanoencapsulation using PLGA on antioxidant and antimicrobial activities of guabiroba fruit phenolic extract. Food Chem. 2018, 240, 396-404. [CrossRef]

44. Elalami, D.; Carrere, H.; Abdelouahdi, K.; Garcia-Bernet, D.; Peydecastaing, J.; Vaca-Medina, G.; Oukarroum, A.; Zeroual, Y.; Barakat, A. Mild microwaves, ultrasonic and alkaline pretreatments for improving methane production: Impact on biochemical and structural properties of olive pomace. Bioresour. Technol. 2020, 299, 122591. [CrossRef]

45. Fedorak, P.M.; Hrudey, S.E. The effects of phenol and some alkyl phenolics on batch anaerobic methanogenesis. Water Res. 1984, 18,361-367. [CrossRef]

46. Chapleur, O.; Mazeas, L.; Godon, J.-J.; Bouchez, T. Asymmetrical response of anaerobic digestion microbiota to temperature changes. Appl. Microbiol. Biotechnol. 2015, 100, 1445-1457. [CrossRef] [PubMed]

47. Rosenkranz, F.; Cabrol, L.; Carballa, M.; Donoso-Bravo, A.; Cruz, L.; Ruiz-Filippi, G.; Chamy, R.; Lema, J. Relationship between phenol degradation efficiency and microbial community structure in an anaerobic SBR. Water Res. 2013, 47, 6739-6749. [CrossRef] [PubMed]

48. Hernandez, J.; Edyvean, R. Inhibition of biogas production and biodegradability by substituted phenolic compounds in anaerobic sludge. J. Hazard. Mater. 2008, 160, 20-28. [CrossRef] [PubMed]

49. Yadav, S.; Chandra, R. Biodegradation of organic compounds of molasses melanoidin (MM) from biomethanated distillery spent wash (BMDS) during the decolourisation by a potential bacterial consortium. Biodegradation 2012, 23, 609-620. [CrossRef] 
50. Peña, M.; Coca, M.; González, G.; Rioja, R.; García, M. Chemical oxidation of wastewater from molasses fermentation with ozone. Chemosphere 2003, 51, 893-900. [CrossRef]

51. Cämmerer, B.; Jalyschkov, V.; Kroh, L.W. Carbohydrate structures as part of the melanoidin skeleton. Int. Congr. Ser. 2002, 1245, 269-273. [CrossRef]

52. Kaushik, A.; Basu, S.; Raturi, S.; Batra, V.; Balakrishnan, M. Recovery of antioxidants from sugarcane molasses distillery wastewater and its effect on biomethanation. J. Water Process. Eng. 2018, 25, 205-211. [CrossRef]

53. Nayak, J.K.; Amit; Ghosh, U.K. An innovative mixotrophic approach of distillery spent wash with sewage wastewater for biodegradation and bioelectricity generation using microbial fuel cell. J. Water Process. Eng. 2018, 23, 306-313. [CrossRef]

54. Prasad, R.K.; Srivastava, S. Electrochemical degradation of distillery spent wash using catalytic anode: Factorial design of experiments. Chem. Eng. J. 2009, 146, 22-29. [CrossRef]

55. Apollo, S.; Onyango, M.S.; Ochieng, A. An integrated anaerobic digestion and UV photocatalytic treatment of distillery wastewater. J. Hazard. Mater. 2013, 261, 435-442. [CrossRef] [PubMed]

56. Siles, J.; García-García, I.; Martín, A. Integrated ozonation and biomethanization treatments of vinasse derived from ethanol manufacturing. J. Hazard. Mater. 2011, 188, 247-253. [CrossRef] [PubMed]

57. Padoley, K.; Saharan, V.K.; Mudliar, S.; Pandey, R.; Pandit, A.B. Cavitationally induced biodegradability enhancement of a distillery wastewater. J. Hazard. Mater. 2012, 219-220, 69-74. [CrossRef] [PubMed]

58. Sangave, P.C.; Gogate, P.R.; Pandit, A.B. Ultrasound and ozone assisted biological degradation of thermally pretreated and anaerobically pretreated distillery wastewater. Chemosphere 2007, 68, 42-50. [CrossRef] [PubMed]

59. Melamane, X.; Tandlich, R.; Burgess, J. Anaerobic digestion of fungally pre-treated wine distillery wastewater. Afr. J. Biotechnol. 2007, 6, 1990-1993. [CrossRef]

60. Romero, C.; Brenes, M.; García, P.; García, A.; Garrido, A. Polyphenol changes during fermentation of naturally black olives. J. Agric. Food Chem. 2004, 52, 1973-1979. [CrossRef]

61. Tsioulpas, A.; Dimou, D.; Iconomou, D.; Aggelis, G. Phenolic removal in olive oil mill wastewater by strains of Pleurotus spp. in respect to their phenol oxidase (laccase) activity. Bioresour. Technol. 2002, 84, 251-257. [CrossRef]

62. Kumar, P.; Chandra, R. Decolourisation and detoxification of synthetic molasses melanoidins by individual and mixed cultures of Bacillus spp. Bioresour. Technol. 2006, 97, 2096-2102. [CrossRef] [PubMed]

63. Santal, A.R.; Singh, N.; Saharan, B.S. Biodegradation and detoxification of melanoidin from distillery effluent using an aerobic bacterial strain SAG5 of Alcaligenes faecalis. J. Hazard. Mater. 2011, 193, 319-324. [CrossRef] [PubMed]

64. Mohana, S.; Desai, C.; Madamwar, D. Biodegradation and decolourization of anaerobically treated distillery spent wash by a novel bacterial consortium. Bioresour. Technol. 2007, 98, 333-339. [CrossRef]

65. Sirianuntapiboon, S.; Zohsalam, P.; Ohmomo, S. Decolorization of molasses wastewater by Citeromyces sp. WR-43-6. Process. Biochem. 2004, 39, 917-924. [CrossRef]

66. Asgher, M.; Bhatti, H.N.; Ashraf, M.; Legge, R. Recent developments in biodegradation of industrial pollutants by white rot fungi and their enzyme system. Biodegradation 2008, 19, 771-783. [CrossRef]

67. Li, W.; Li, X.; Zeng, K. Aerobic biodegradation kinetics of tannic acid in activated sludge system. Biochem. Eng. J. 2009, 43, 142-148. [CrossRef]

68. Lin, J.; Reddy, M.; Moorthi, V.; Qoma, B.E. Bacterial removal of toxic phenols from an industrial effluent. Afr. J. Biotechnol. 2008, 7, 2232-2238.

69. Kanimozhi, R.; Vasudevan, N. Effect of organic loading rate on the performance of aerobic SBR treating anaerobically digested distillery wastewater. Clean Technol. Environ. Policy 2014, 16, 467-476. [CrossRef]

70. Anupama, S.; Pradeep, N.V.; Hampannavar, U.S. Anaerobic followed by aerobic treatment approaches for Spentwash using MFC and RBC. Sugar Tech 2013, 15, 197-202. [CrossRef]

71. Sundararaman, S.; Kumar, J.L.; Kumar, N.G. Reduction of COD and decolourisation of UASB spent wash using E-MBR. Res. J. Pharm. Technol. 2015, 8, 845-848. [CrossRef]

72. Gupta, R.; Satyawali, Y.; Batra, V.S.; Balakrishnan, M. Submerged membrane bioreactor using fly ash filters: Trials with distillery wastewater. Water Sci. Technol. 2008, 58, 1281-1284. [CrossRef] [PubMed]

73. Deschamps, L.; Merlet, D.; Lemaire, J.; Imatoukene, N.; Filali, R.; Clément, T.; Lopez, M.; Theoleyre, M.-A. Excellent performance of anaerobic membrane bioreactor in treatment of distillery wastewater at pilot scale. J. Water Process. Eng. 2021, $41,102061$. [CrossRef]

74. Travieso, L.; Benítez, F.; Sánchez, E.; Borja, R.; León, M.; Raposo, F.; Rincon, B. Assessment of a microalgae pond for post-treatment of the effluent from an anaerobic fixed bed reactor treating distillery wastewater. Environ. Technol. 2008, 29, 985-992. [CrossRef] [PubMed]

75. Ray, S.G.; Ghangrekar, M.M. Comprehensive review on treatment of high-strength distillery wastewater in advanced physicochemical and biological degradation pathways. Int. J. Environ. Sci. Technol. 2019, 16, 527-546. [CrossRef]

76. Lasik, M.; Gumienna, M.; Szambelan, K.; Czarnecki, Z. Water and energy saving bioprocess for bioethanol production from corn grain applying stillage liquid part recirculation. Afr. J. Biotechnol. 2013, 12, 5950-5955. [CrossRef]

77. Pejin, D.; Mojovic, L.; Grujic, O.; Pejin, J.; Rakin, M. The bioethanol production with the thin stillage recirculation. Chem. Ind. Chem. Eng. Q. 2009, 15, 49-52. [CrossRef] 
78. Gumienna, M.; Lasik, M.; Szambelan, K.; Czarnecki, Z. Reduction of water consumption in bioethanol production from triticale by recycling the stillage liquid phase. Acta Sci. Pol. Technol. Aliment. 2012, 10, 467-474.

79. Mikulski, D.; Kłosowski, G. Efficiency of dilute sulfuric acid pretreatment of distillery stillage in the production of cellulosic ethanol. Bioresour. Technol. 2018, 268, 424-433. [CrossRef]

80. Mikulski, D.; Kłosowski, G. Hydrotropic pretreatment on distillery stillage for efficient cellulosic ethanol production. Bioresour. Technol. 2020, 300, 122661. [CrossRef]

81. Davis, L.; Jeon, Y.-J.; Svenson, C.; Rogers, P.; Pearce, J.; Peiris, P. Evaluation of wheat stillage for ethanol production by recombinant Zymomonas mobilis. Biomass Bioenergy 2005, 29, 49-59. [CrossRef]

82. Das, D. Hydrogen production by biological processes: A survey of literature. Int. J. Hydrogen Energy 2001, 26, 13-28. [CrossRef]

83. Puyol, D.; Batstone, D.J.; Hülsen, T.; Astals, S.; Peces, M.; Krömer, J. Resource recovery from wastewater by biological technologies: Opportunities, challenges, and prospects. Front. Microbiol. 2017, 7, 2106. [CrossRef]

84. Singh, H.; Das, D. Biofuels from microalgae: Biohydrogen. Green Energy Technol. 2018, 2018, 201-228. [CrossRef]

85. Laurinavichene, T.; Tekucheva, D.; Laurinavichius, K.; Tsygankov, A. Utilization of distillery wastewater for hydrogen production in one-stage and two-stage processes involving photofermentation. Enzym. Microb. Technol. 2018, 110, 1-7. [CrossRef] [PubMed]

86. Mishra, P.; Roy, S.; Das, D. Comparative evaluation of the hydrogen production by mixed consortium, synthetic co-culture and pure culture using distillery effluent. Bioresour. Technol. 2015, 198, 593-602. [CrossRef] [PubMed]

87. Balachandar, G.; Varanasi, J.L.; Singh, V.; Singh, H.; Das, D. Biological hydrogen production via dark fermentation: A holistic approach from lab-scale to pilot-scale. Int. J. Hydrogen Energy 2020, 45, 5202-5215. [CrossRef]

88. Searmsirimongkol, P.; Rangsunvigit, P.; Leethochawalit, M.; Chavadej, S. Hydrogen production from alcohol distiller wastewater containing high potassium and sulfate using an anaerobic sequencing batch reactor. Int. J. Hydrogen Energy 2011, 36, 12810-12821. [CrossRef]

89. Cheng, H.-H.; Whang, L.-M.; Chung, M.-C.; Chan, K.-C. Biological hydrogen and methane production from bagasse bioethanol fermentation residues using a two-stage bioprocess. Bioresour. Technol. 2016, 210, 49-55. [CrossRef] [PubMed]

90. Malik, S.N.; Pugalenthi, V.; Vaidya, A.N.; Ghosh, P.C.; Mudliar, S.N. Kinetics of nano-catalysed dark fermentative hydrogen production from distillery wastewater. Energy Procedia 2014, 54, 417-430. [CrossRef]

91. Roy, S.; Ghosh, S.; Das, D. Improvement of hydrogen production with thermophilic mixed culture from rice spent wash of distillery industry. Int. J. Hydrogen Energy 2012, 37, 15867-15874. [CrossRef]

92. Lazaro, C.Z.; Varesche, M.B.A.; Silva, E. Sequential fermentative and phototrophic system for hydrogen production: An approach for Brazilian alcohol distillery wastewater. Int. J. Hydrogen Energy 2015, 40, 9642-9655. [CrossRef]

93. Hiremath, S.G.; Joshi, S.G. Roadmap to distillery spent wash treatment and use of soft computing techniques. Evol. Intell. 2020, 1-15. [CrossRef]

94. Geetha, K.; Raj, S.A. Biomass-electrochemical integrated system for distillery wastewater treatment with electricity generation using anaerobic mixed consortium in microbial fuel cells. Int. J. Environ. Waste Manag. 2015, 15, 217. [CrossRef]

95. Samsudeen, N.; Radhakrishnan, T.; Matheswaran, M. Bioelectricity production from microbial fuel cell using mixed bacterial culture isolated from distillery wastewater. Bioresour. Technol. 2015, 195, 242-247. [CrossRef]

96. Mohanakrishna, G.; Mohan, S.V.; Sarma, P. Bio-electrochemical treatment of distillery wastewater in microbial fuel cell facilitating decolorization and desalination along with power generation. J. Hazard. Mater. 2010, 177, 487-494. [CrossRef] [PubMed]

97. Samsudeen, N.; Radhakrishnan, T.K.; Matheswaran, M. Performance comparison of triple and dual chamber microbial fuel cell using distillery wastewater as a substrate. Environ. Prog. Sustain. Energy 2015, 34, 589-594. [CrossRef]

98. Sonawane, J.; Marsili, E.; Ghosh, P.C. Treatment of domestic and distillery wastewater in high surface microbial fuel cells. Int. J. Hydrogen Energy 2014, 39, 21819-21827. [CrossRef]

99. Sonawane, J.; Gupta, A.; Ghosh, P.C. Multi-electrode microbial fuel cell (MEMFC): A close analysis towards large scale system architecture. Int. J. Hydrogen Energy 2013, 38, 5106-5114. [CrossRef]

100. Mohanakrishna, G.; Mohan, S.K. Carbon based nanotubes and nanopowder as impregnated electrode structures for enhanced power generation: Evaluation with real field wastewater. Appl. Energy 2012, 95, 31-37. [CrossRef]

101. Lin, C.-W.; Wu, C.-H.; Huang, W.-T.; Tsai, S.-L. Evaluation of different cell-immobilization strategies for simultaneous distillery wastewater treatment and electricity generation in microbial fuel cells. Fuel 2015, 144, 1-8. [CrossRef]

102. Quan, X.; Tao, K.; Mei, Y.; Jiang, X. Power generation from cassava alcohol wastewater: Effects of pretreatment and anode aeration. Bioprocess Biosyst. Eng. 2014, 37, 2325-2332. [CrossRef] [PubMed]

103. Huang, J.; Yang, P.; Guo, Y.; Zhang, K. Electricity generation during wastewater treatment: An approach using an AFB-MFC for alcohol distillery wastewater. Desalination 2011, 276, 373-378. [CrossRef] 